\title{
STRATEGI PENDIDIKAN AKHLAK PADA ANAK
}

\author{
Amin Zamroni \\ Universitas Islam Sultan Agung (Unissula) Semarang \\ e-mail: aminzamroni91@gmail.com
}

\begin{abstract}
Abstrak
Moral education for children should be done as early as possible. So when they grow into adult, they have good personality. Parents especially mother has the most important role to educate their children because she is the first madrasah for her children. A child is like a clean white paper with no stain, while parents have freedom to paint any colors as they want. Good and bad morality depends on the education provided by their parents. Therefore, parents and teachers should have such methods to educate their children at home and school in order to become a shalih-shalihah children. The moral education methods include habituation, exemplary method, advice and attention. Furthermore, moral education strategy is divided into two namely direct and indirect educations. Direct education includes exemplary, suggestion, and practice. While indirect education includes prohibition, punishment, reward and supervision.
\end{abstract}

Pendidikan akhlak pada anak-anak harus dilakukan sedini mungkin. Sehingga ketika dewasa anak tersebut mempunyai akhlak yang mulia. Orang tua terutama ibu mempunyai peran paling penting dalam mendidik anaknya, karena ia merupakan madrasah pertama bagi anak-anaknya. Seorang anak ibarat kertas putih bersih tanpa noda, sedangkan orang tua mempunyai kebebasan untuk memberikan warna apapun sesuai dengan apa yang mereka inginkan. Baik dan buruknya akhlak anak tergantung pada pendidikan yang diberikan oleh orang tuanya. Oleh karena itu, orang tua maupun guru yang akan mendidik anak di rumah maupun disekolahan harus mempunyai metode, agar nantiya bisa mendidik anak dengan baik dan menjadi anak yang shalih-shalihah. Metode pendidikan akhlak diantaranya adalah metode pembiasaan, metode keteladanan, metode nasihat dan metode perhatian. Kemudian untuk strategi pendidikan akhlaknya ini dibagi menjadi dua yaitu pendidikan langsung dan pendidikan tidak langsung. Pendidikan langsung diantaranya adalah keteladanan, anjuran, latihan. Pendidikan tidak langsung diantaranya adalah larangan, hukuman, hadiah dan pengawasan.

Kata Kunci: strategi pendidikan; akhlak; anak 


\section{A. Pendahuluan}

Pendidikan adalah bimbingan secara sadar oleh pendidik terhadap perkembangan jasmani dan ruhani terdidik menuju terbentuknya kepribadian yang utama. ${ }^{1}$ Pendidikan hanya merupakan penyampaian materi yang hampa dari nilai-nilai spiritual, padahal ilmu pengetahuna lebih berbahaya jika tidak dihiasi dengan akhlak mulia. ${ }^{2}$ Sedangkan, Pendidikan akhlak adalah proses mendidik, memelihara, membentuk, memberikan latihan mengenai akhlak dan kecerdasan berfikir baik yang bersifat formal maupun informal yang didasarkan pada ajaranajaran Islam. ${ }^{3}$ Dalam sistem pendidikan Islam menekankan pada pendidikan akhlak yang seharusnya dimiliki oleh seorang Muslim agar memiliki kepribadian seorang Muslim. Mohammad Athiyah al-Abrasyi menjelaskan: "Pendidikan budi pekerti jiwa adalah jiwa dari pendidikan Islam dan Islam telah menyimpulkan bahwa pendidikan budi pekerti dan akhlak adalah jiwa pendidikan Islam. Mencapai akhlak yang sempurna adalah tujuan sebenarnya dari pendidikan."4

Akhlak merupakan asas pokok bagi umat Islam, sebagaimana diangkatnya Nabi Muhammad sebagai Rasulullah, hanya untuk menyempurnakan akhlak manusia. Karena itu, pendidikan akhlak terhadap anak, menjadi fokus utama dalam Islam. Hal tersebut disjelaskan oleh Rasulullah:

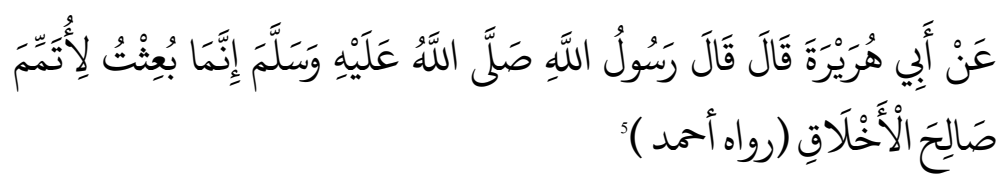

Dari Abi Hurairah berkata, Rasulullah bersabda: "Sesungguhnya saya diutus tidak lain hanyalah untuk menyempurnakan akhlak." (HR. Imam Ahmad)

Dalam Ensiklopedia al-Qur'an dijelaskan:

${ }^{1}$ Mahmud, Pemikiran Pendidikan Islam, (Bandung: Setia Pustaka, 2011), h. 21.

${ }^{2}$ Muhammad Syakir, Washaya al-Aba' lil-Abna', (Semarang: Alawiyah, t.th.), h. 4.

'Yatimin Abdullah, Studi Akhlak dalam Perspektif al-Qur'an, (Jakarta: Sinar Grafika Offset, 2007), h. 23.

${ }^{4}$ Abuddin Nata, Akhlak Tasawuf, (Jakarta, Rajawali Pers, 2010), h. 37.

${ }^{5}$ Abu Abdullah Ahmad bin Muhammad bin Hanbal bin Hilal bin Asad al-Syaibani, Musnad Ahmad, Juz 14, Maktabah Syamilah, h. 512. 
"Allah memilih Nabi Muhammad bin Abdullah untuk mengemban risalah Islam. Dia yang Maha Bijaksana dan Maha Tahu memelihara nabi Muhammad yang yatim sejak lahir dan mempercayakannya untuk mengemban risalah Islam. Akhlak dan watak nabi Muhammad yang mulia serta kemanusiannya yang luhur sangat berpengaruh dalam mengorbankan revolusi terbesar dan termulia yang pernah dikenal manusia sejak Allah memerintahkan Adam dan Hawa turun dari surga hingga saat ini. Dakwah Islam yang dibawa nabi Muhammad adalah revolusi Akhlak."

Pendidikan akhlak terhadap anak sangat penting. Karena, dalam siklus kehidupan manusia, masa kanak-kanak merupakan sebuah masa yang paling penting, sekaligus merupakan masa yang sangat berbahaya. Jika tidak dididik atau diperhatikan secara benar oleh para orang tua, maka nantinya anak tumbuh dalam keadaan akhlak yang kurang baik. Sebab, seorang anak pada hakikatnya telah tercipta dengan kemampuan untuk menerima kebaikan maupun keburukan. Kedua orang tuanyalah yang membuatnya cenderung kearah salah satu dari keduanya. ${ }^{7}$

Rasulullah bersabda:

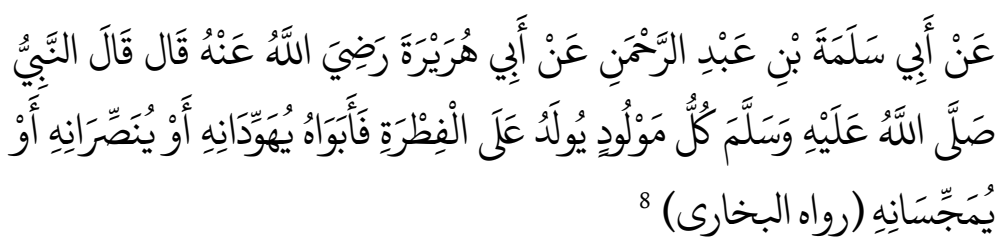

Dari Abi Salamah bin Abdur Rohman dari Abu Hurairah berkata: Rasulullah bersabda: "Setiap anak dilahirkan dalam keadaan fitrah (bersih dan suci), maka kedua orang tuanyalah yang membuatnya menjadi Yahudi, Nasrani ataupun Majusi”. (HR. Imam Bukhari)

Pendidikan akhlak sangat penting bagi anak, agar kelak tumbuh menjadi generasi yang membanggakan orang tua. Oleh karenanya para orang tua perlu

${ }^{6}$ Muhamad Kamil Hasan al-Mahani, Ensiklopedia al Qur'an, terj. Ahmad Fawaid Syadzili, (Jakarta: Kharisma Ilmu, 2005), h. 8.

${ }^{7}$ George S. Morrison, Dasar-dasar Pendidikan Anak Usia Dini (PAUD), (Jakarta: Indeks, 2012), h. 32.

${ }^{8}$ Muhammad Isma'il bin Ibrahim bin al-Mughirah al-Bukhari, Shahih Bukhari, Juz 5, Maktabah Syamilah, h. 182. 
menjadikan pendidikan sebagai salah satu pokok penting dalam pendidikan anak. Rasulullah bersabda:

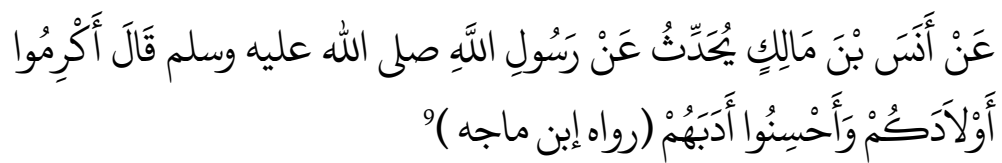

Dari Anas bin Malik dari Rasulullah bersabda: "Sayangilah anak-anak kalian dan didiklah mereka dengan adab yang mulia" (HR. Ibnu Majjah)

Keluarga merupakan pendidikan pertama dan utama bagi anak, karena yang terjadi dalam keluarga sangat membawa pengaruh terhadap kehidupan anak. Keluarga (orang tua) tidak sepenuhnya mampu memberikan pendidikan kepada anak-anaknya secara sempurna, maka dari itu dibutuhkan lembaga pendidikan formal atau sekolah untuk menumbuh kembangkan potensi anak.

Sekolah sebagai tempat pendidikan kedua setelah keluarga, merupakan sebuah lembaga yang sangat penting bagi anak dalam upaya mengajarkan ajaran Islam sebagai pandangan hidup anak. Seiring dengan perkembangan zaman masa kini, banyak sekali tantangan yang dihadapi oleh umat manusia. Ini semua disebabkan karena adanya kemunduran moral umat manusia dengan berbagai kehidupan dalam masyarkat. Dengan adanya pendidikan akhlak anak, seharusnya umat manusia harus menjadi lebih baik, karena sejak kecil umat manusia telah dibekali dengan pendidikan akhlak. Namun pada kenyataanya, banyak dari umat manusia pada modern ini yang banyak mengalami krisis akhlak. Ini semua disebabkan adanya perkembangan teknologi yang begitu cepat.

Strategi (rencana tindakan yang terdiri atas seperangkat langkah untuk memecahakan masalah atau mencapai tujuan) yang harus dilakukan oleh orang tua maupun oleh guru dalam mendidik akhlak kepada anak, sebaiknya menggunakan beberapa metode diantara keteladanan atau pembiasaan tentang sikap yang baik, tanpa adanya keteladanan atau pembiasaan tentang sikap yang baik pendidikan tersebut akan sulit mencapai tujuan yang diharapkan, dan sudah

9al-Hafidz Abi ‘Abdillah Muhammad bin Yazid al-Qozwini, Sunan Ibnu Majjah, Juz II, (Beirut: Dar al-Fikr, t.th.), h. 1211. 
menjadi kewajiban orang tua dan guru untuk memberikan keteladanan atau contoh yang baik dan membiasakannya bersikap baik pula.

Oleh karena itu, penanaman pendidikan akhlak pada masa anak-anak sangatlah penting, agar anak memiliki bekal untuk hidup selanjutnya. Pendidikan akhlak harus dilakukan sejak dini, sebelum watak dan kepribadiannya terpengaruh lingkungan yang tidak paralel dengan tuntunan agama. ${ }^{10}$ Seorang anak ibarat kertas putih, apabila kertas itu ditulis dengan tinta warna merah, maka kertas menjadi merah, apabila kertas ditulis warna hijau, maka kertas menjadi hijau. Semua bergantung pada pola pendidikan yang diberikan oleh orang tua kepada anaknya. Maka dari itu diperlukan sebuah strategi dalam mendidik anak, agar anak nantinya mempunyai akhlak yang mulia yang bisa membanggakan orang tuanya dan bisa menjadi syafa'at kelak di akhirat nanti.

\section{B. Pengertian Pendidikan}

Sebelum dipaparkan mengenai pengertian pendidikan akhlak, maka terlebih dahulu dibahas beberapa pendapat tentang pengertian pendidikan. Pendidikan berasal dari kata didik, yaitu memelihara dan memberi latihan mengenai akhlak dan kecerdasan pikiran.

Dalam Kamus Besar Bahasa Indonesia dijelaskan bahwa pendidikan adalah proses pengubahan sikap dan tata laku seseorang atau kelompok orang dalam usaha mendewasakan manusia melalui upaya pengajaran dan pelatihan ${ }^{11}$

Pendidikan ialah proses membimbing manusia dari kegelapan, kebodohan, dan pencerahan pengetahuan. Dalam arti luas pendidikan baik formal maupun informal meliputi segala hal yang memperluas pengetahuan manusia tentang dirinya sendiri dan tentang dunia tempat mereka hidup. Menurut caranya pendidikan terbagi atas tiga macam, yaitu: 1) Pressure, yaitu pendidikan berdasarkan paksaan (secara paksa). 2) Latihan untuk membentuk kebiasaan. 3) Pendidikan dimaksudkan untuk membentuk hati nurani yang baik. ${ }^{12}$

Menurut Ahmad D. Marimba, pendidikan adalah bimbingan atau pimpinan secara sadar oleh pendidik terhadap perkembangan jasmani dan ruhani

\footnotetext{
${ }^{10} \mathrm{http}: / /$ www.piss-ktb.com, diakses tanggal 1 Januari 2017.

${ }^{11}$ Departemen Pendidikan Nasional, Kamus Besar Bahasa Indonesia, Jakarta: Gramedia Pustaka Utama, 2013), h. 326.

${ }^{12} \mathrm{Ibid}$.
} 
terdidik menuju terbentuknya kepribadian yang utama atau insan kamil. ${ }^{13}$ Hasan Langgulung memberi pengertian tentang Pendidikan adalah sebagai salah satu upaya penting pewarisan kebudayaan yang dilakukan oleh generasi tua kepada generasi muda agar kehidupan tetap berlanjut. Dalam Sistem Pendidikan Nasional Pendidikan diartikan sebagai usaha sadar dan terencana untuk mewujudkan suasana belajar dan proses pembelajaran agar peserta didik secara aktif mengembangkan potensi dirinya untuk memiliki kekuatan spiritual keagamaan, pengendalian diri, kepribadian, kecerdasan, akhlak mulia, serta ketrampilan, yang diperlukan dirinya, masyarakat, bangsa dan Negara. ${ }^{14}$

Dari beberapa pendapat yang telah diuraikan secara terinci, maka penulis dapat menyimpulkan, bahwa pendidikan adalah suatu usaha sadar melalui bimbingan, pengarahan, dan atau latihan untuk membantu dan mengarahkan anak didik agar berkepribadian tinggi menuju hidup sempurna serta mampu melaksanakan kewajibannya terhadap agama dan negara.

Dalam konteks Islam istilah pendidikan telah dikenal dengan banyak istilah yang beragam yaitu at-tarbiyah, at-ta'lim, dan at-ta'dib. Dari setiap istilah tersebut mempunyai makna yang berbeda-beda. Walaupun dalam beberapa hal mempunyai arti yang sama.

\section{1. al-Tarbiyah}

Kata tarbiyah berasal dari kata ربي - يربي - تربيةyang berarti memelihara, mendidik, mengasuh. Menurut Ibnu Abdillah Muhammad bin Ahmad alAnshari al-Qurthubi mengartikan bahwa rabb adalah pemilik, maha memperbaiki, maha mengatur, maha menambah, maha menunaikan. Sedangkan menurut al-Jauhari adalah memberi makan, memelihara, mengasuh. ${ }^{15}$ Dalam alQur'an kata "rabba" ini digunakan untuk Tuhan, karena Tuhan sifatnya mendidik, mengasuh, memelihara dan pencipta.

\section{b. al-Ta'lim}

Kata ta'lim berasal dari kata 'allama yang berarti proses transmisi ilmu pengetahuan atau sama dengan pengajaran, yang sering disebut dengan transfer of

\footnotetext{
${ }^{13}$ Mahmud, Pemikiran Pendidikan Islam h. 21.

${ }^{14}$ Undang-undang Sistem Pendidikan Nasional, (Bandung: Fokus Media, 2009), h. 2 .

${ }^{15}$ Yatimin Abdullah, Studi Akhlak dalam Perspektifal-Qur'an, h. 22.
} 
knowledge. Menurut Naquib al-Attas adalah proses pengajaran tanpa adanya pengenalan secara mendasar yaitu memberikan atau mengajarkan suatu ilmu pengetahuan kepada peserta didik. ${ }^{16}$

\section{c. al-Ta'dib}

Kata al-ta'dib berasal dari kata 'Adaba yang berarti bersopan santun atau beradab. Seseorang dalam menuntut ilmu harus mempunyai sopan santun agar ilmu sedang dipelajari bisa bermanfaat dan diridloi oleh Allah. Menurut Naquib al Attas ta'dib adalah proses mengenalkan ilmu pengetahuan secara berangsurangsur kepada diri manusia dalam tatanan penciptaan, kemudian membimbing dan mengarahkannya pada pengakuan dan pengenalan kekuasaan, keagungan Tuhan di dalam tatanan wujud dan keberadaannya. ${ }^{17}$

\section{Pengertian Akhlak}

Adapun akhlak menurut Hamzah Ya'qub berasal dari bahasa Arab, jamak dari kata "khuluqun", artinya tindakan. Kata "khuluqun" sepadan dengan kata "khalqun", artinya kejadian dan kata "khaliqun". Artinya pencipta dan kata "makhluqun", artinya yang diciptakan. Dengan demikian, rumusan terminologis dari akhlak merupakan hubungan erat antara Khaliq dengan makhluq serta antara makhluq dengan makhluq. ${ }^{18}$

Dalam Ensiklopedi Islam akhlak adalah suatu keadaan yang melekat pada jiwa manusia, yang daripadanya lahir perbuatan-perbuatan dengan mudah, tanpa melalui proses pemikiran, pertimbangan atau penelitian. ${ }^{19}$ Jika keadaan tersebut melahirkan perbuatan yang baik dan terpuji, disebut akhlaq mahmudah. Sedangkan, jika perbuatan-perbuatan yang timbul itu tidak baik, disebut akhlaq madzmumah. Akhlak merupakan suatu keadaan yang melekat di dalam jiwa, maka suatu perbuatan dapat disebut akhlak kalau terpenuhi beberapa syarat: 1) Perbuatan itu dilakukan berulang-ulang. Kalau suatu perbuatan hanya sesekali saja, maka tidak disebut akhlak. 2) Perbuatan itu timbul dengan mudah tanpa dipikirkan atau diteliti terlebih dahulu sehingga ia benar-benar merupakan suatu

\footnotetext{
${ }^{16}$ Ibid.

${ }^{17}$ Ibid., h. 23.

${ }^{18}$ Beni Ahmad Saebani, Abdul Hamid, Ilmu Akhlak, (Bandung: Pustaka Setia, 2010), h. 14.

${ }^{19}$ Hafizh Dasuki, et. al, Ensiklopedi Islam, Juz I, (Jakarta: Ichtiar Baru van Hoeve, 1994), h. 102.
} 
kebiasaan. Jika perbuatan itu timbul karena terpaksa atau setelah dipikirkan dan dipertimbangkan secara matang, maka tidak disebut akhlak. ${ }^{20}$

Menurut Ibnu Maskawaih akhlak adalah sifat yang tertanam dalam jiwa yang mendorongnya untuk melakukan perbuatan tanpa memerlukan pemikiran dan pertimbangan. ${ }^{21}$

Sedangkan menurut Imam al-Ghazali, akhlak adalah:

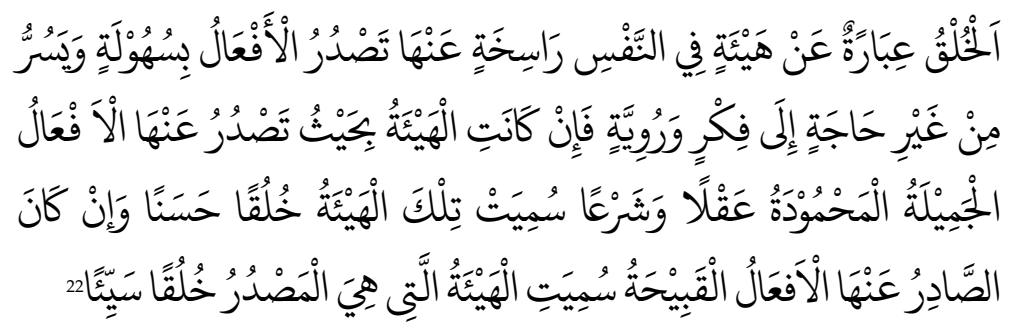

"Akhlak adalah suatu kemantapan (jiwa) yang menghasilkan perbuatan atau pengamalan dengan mudah tanpa perlu pemikiran dan pertimbangan, jika kemantapan itu sedemikian sehingga menghasilkan amal-amal yang baik, yaitu amal yang baik menurut akal dan syariah, maka itu disebut akhlak yang baik. Jika amal-amal yang muncul dari keadaan (kemantapan) itu amal yang tercela, maka itu dinamakan akhlak yang buruk." ${ }_{23}$

Dari definisi tersebut, dapat diketahui bahwa hakikat akhlak menurut alGhazali mencakup dua syarat: 1) Perbuatan itu harus konstan, yaitu dilakukan berulang kali dalam bentuk yang sama sehingga dapat menjadi kebiasaan. Misalnya: seseorang yang memberikan sumbangan harta hanya sekali-sekali karena dorongan keinginan sekonyong-konyong saja, maka orang itu tidak dapat dikatakan sebagai pemurah selama sifat demikian itu belum tetap dan meresap dalam jiwa. 2) Perbuatan yang konstan itu harus tumbuh dengan mudah sebagai wujud refleksi dari jiwanya tanpa pertimbangan dan pemikiran, yakni bukan karena adanya tekanan-tekanan, paksaan-paksaan dari orang lain, atau pengaruh-pengaruh dan

\footnotetext{
${ }^{20} \mathrm{Ibid}$.

${ }^{21}$ Beni Ahmad Saebani, Abdul Hamid, Ilmu Akhlak, h. 14.

${ }^{22}$ Imam al-Ghazali, Ihya Ulumudin, (Jeddah Indonesia: 1 Haramain, t.th.), Jilid III, h. 52.

${ }^{23}$ Imam al-Ghazali, Ihya 'Ulum ad-Din, terj. Ismail Ya'kub, (Jakarta: Faisan 1986), Jilid IV, h. 143.
} 
bujukan-bujukan indah dan sebagainya. Misalnya: orang yang memberikan harta benda karena tekanan moral dan pertimbangan. Maka belum juga termasuk kelompok orang yang bersifat pemurah. Pemurah sebagai sifat dan sikap yang melekat dalam pribadi yang didapat karena didikan atau memang naluri ${ }^{24}$

Jadi, menurut penulis akhlak adalah sikap yang melekat pada diri seseorang dan secara spontan diwujudkan dalam tingkah laku atau perbuatan. Jika tindakan spontan itu baik menurut pandangan akal agama, maka tindakan tersebut dinamakan akhlak yang baik (akhlaqul karimah/akhlaqul mahmudah), dan sebaliknya jika tindakan spontan itu jelek, maka disebut akhlaqul madzmumah. Akhlak adalah implementasi dari iman dalam segala bentuk perilaku. Semakin kuat keimanan seseorang, makin luhur pula akhlaknya. Rasulullah bersabda:

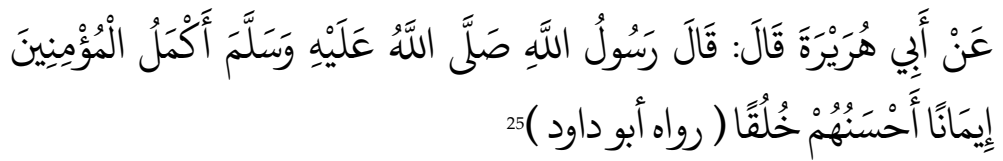

Dari Abi Hurairah berkata: Rasulullah bersabda: "orang mukmin yang paling sempurna imannya adalah mereka yang paling luhur akhlaknya". (HR. Abu Daud)

Dari pengertian-pengertian di atas, penulis berpandangan bahwa hakikatnya pendidikan akhlak adalak usaha menanamkan dasar-dasar moral dan keutamaan perangai, tabi'at yang harus dimiliki dan dijadikan kebiasaan dengan harapan agar si terdidik memiliki pengertian tentang baik buruknya suatu perbuatan, dapat mengamalkan ajaran Islam, memiliki keyakinan yang teguh dan berakhlak mulia yang pada akhirnya agar menjadi manusia yang utama atau insanul kamil. Usaha tersebut dilakukan secara bertahap melalui proses yang berkesinambungan seirama dengan perkembangan anak didik.

\section{Pendidikan Akhlak pada Anak}

Masa kanak-kanak adalah merupakan masa yang paling subur, paling panjang, dan paling dominan bagi seorang murabbi (pendidik) untuk menanam102-103.

${ }^{24}$ Zainudin, dkk, Seluk Beluk Pendidikan dari al-Ghazali, (Jakarta: Bumi Aksara, 1991), h.

${ }^{25} \mathrm{Abu}$ Daud Sulaiman bin al-Asy'at bin Ishaq bin Basyir bin Syadad bin Umar al-Azdi al-Sajistani, Sunan Abu Dawud, Juz 12, Maktabah Syamilah, h. 292. 
kan norma-norma yang mapan dan arahan yang bersih dalam jiwa. Berbagai kesempatan terbuka lebar untuk sang murabbi dan semua potensi tersedia secara berlimpah dalam fase ini dengan adanya fitrah yang bersih, masa kanak-kanak yang masih lugu, kepolosan yang begitu jernih, kelembutan dan kelenturan jasmaninya, kalbu yang masih belum tercemari, dan jiwa yang masih belum terkontaminasi. Apabila masa kanak-kanak dapat dimanfaatkan seorang murabbi secara maksimal dengan sebaik-baiknya, tentu harapan yang besar untuk berhasil, mudah diraih pada masa mendatang, sehingga kelak sang anak akan tumbuh menjadi seorang pemuda yang tahan dalam mengahadapi berbagai macam tantangan, beriman, kuat kokoh, lagi tegar.

Al-Qur'an telah memberikan gambaran yang jelas mengenai pendidikan akhlak pada anak-anak yang tertuang dalam surat Lukman.

\section{Akhlak kepada Allah}

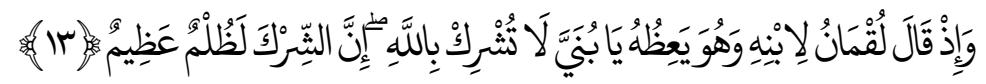

"Dan (ingatlah) ketika Luqman berkata kepada anaknya, di waktu ia memberi pelajaran kepadanya: "Hai anakku, janganlah kamu mempersekutukan Allah, Sesungguhnya mempersekutukan (Allah) adalah benar-benar kezaliman yang besar." (QS. Luqman [31]: 13)

Ayat tersebut mengisyaratkan bagaimana seharusnya para orang tua mendidik anaknya untuk mengesakan penciptanya dan memegang prinsip tauhid dengan tidak menyekutukan Tuhannya. Bahwa pesan tersebut yang berbentuk larangan, jangan mempersekutukan Allah untuk perlunya meninggalkan sesuatu yang buruk sebelum melaksanakan yang baik. ${ }^{26}$ Kemudian anak-anak hendaklah diajarkan untuk mengerjakan shalat. Sehingga terbentuk manusia yang senantiasa kontak dengan penciptanya.

Imam al-Ghazali menjelaskan bahwa seorang anak yang telah mencapai usia tamyiz, maka hendaklah tidak dibiarkan meninggalkan thaharah dan shalat. Juga mulai diperintahkan berpuasa beberapa hari di bulan Ramadhan. ${ }^{27}$ Nabi Muhammad bersabda:

${ }^{26}$ M. Quraish Shihab, Tafsir al-Mishbah, Juz 11, (Jakarta: Lentera Hati, 2005), h. 127.

${ }^{27}$ Imam al-Ghazali, Ihya 'Ulum ad-Din, terj. Ismail Ya'kub, h. 197. 


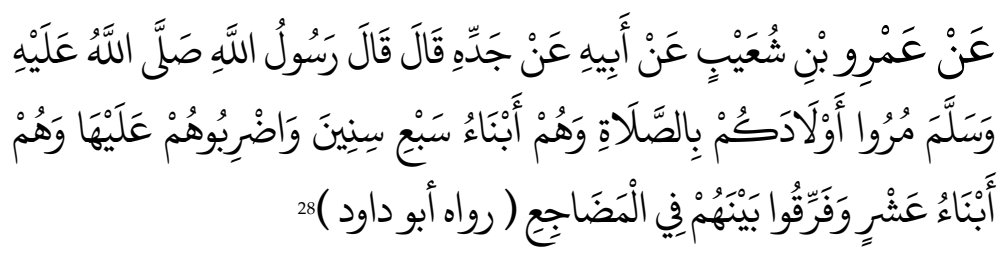

Dari Umar bin Syu'aib dari bapaknya dari kakeknya berkata: Rasulullah bersabda:"perintahkanlah kepada anak-anak kalian untuk mengerjakan shalat bila mulai berusia 7 tahun dan pukullah mereka karena meninggalkannya karena telah berusia 10 tahun, dan pisahkanlah mereka dari tempat tidurnya masing-masing." (HR. Abu Dawud).

Syaikh Muhammad Syakir menjelaskan dalam kitabnya washoya al aba' lil abna sesungguhnya Allah mengetahui apa yang disembunyikan hamba di dalam dadanya, yang dinyatakan dalam lisannya dan mengetahui semua amalnya. Maka, bertakwalah kepada Allah, jangan sampai Allah melihat dalam keadaan yang tidak diridhai, agar Allah tidak murka. Karena, Dia-lah yang menciptakan manusia, memberi rezeki dan akal yang digunakan untuk bertindak dalam berbagai urusannya. ${ }^{29}$

\section{Akhlak kepada Orang Tua}

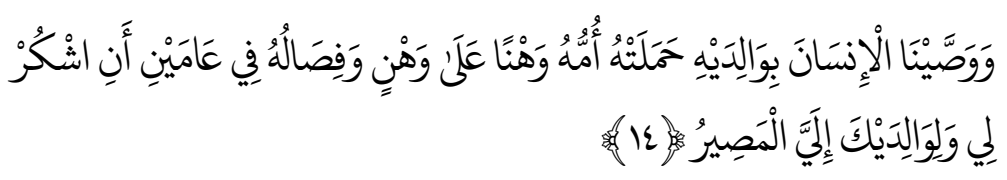

"Dan Kami perintahkan kepada manusia (berbuat baik) kepada dua orang ibu- bapanya; ibunya telah mengandungnya dalam Keadaan lemah yang bertambah- tambah, dan menyapihnya dalam dua tahun. Bersyukurlah kepadaku dan kepada dua orang ibu bapakmu, hanya kepada-Kulah kembalimu." (QS. Luqman [31]: 14)

Islam mendidik anak-anak untuk selalu berbuat baik terhadap orang tua sebagai rasa terima kasih atas perhatian, kasih sayang dan semua yang telah mereka lakukan untuk anak-anaknya. Al-Ghazali menegaskan bahwa seorang

\footnotetext{
${ }^{28} \mathrm{Abu}$ Daud Sulaiman bin al-Asy'at bin Ishaq bin Basyir bin Syadad bin Umar al-Azdi as-Sajistani Sunan Abi Daud, Juz 2, Maktabah Syamilah, h. 88

${ }^{29}$ Syaikh Muhammad Syakir, Washaya al-Aba' lil-Abna', h. 11.
} 
anak haruslah dididik untuk selalu taat kepada kedua orang tuanya, gurunya serta yang bertanggung jawab atas pendidikannya. Hendaklah menghormati mereka serta siapa saja yang lebih tua daripadanya, agar senantiasa bersikap sopan dan tidak bercanda atau bersenda gurau dihadapan mereka. ${ }^{30}$

Syaikh Muhammad Syakir menjelaskan dalam kitabnya Washaya al-Aba' litAbna' bahwa seorang anak harus mendahulukan kepentingan orang tuanya daripada dirinya sendiri. Seorang anak hendaklah berhati-hati terhadap orang tuanya untuk tidak membuat marah, karena sesungguhnya kemarahan Allah berkaitan dengan kemarahan kedua orang tua. Barangsiapa membuat Allah murka, karena membuat kemarahan orang tua, maka dia akan merugi dunia akhirat. Seorang anak harus taat kepada perintah orang tuanya dan dilarang untuk membantahnya, kecuali bila mereka memerintahkan untuk ingkar kepada Allah. Allah berfirman:

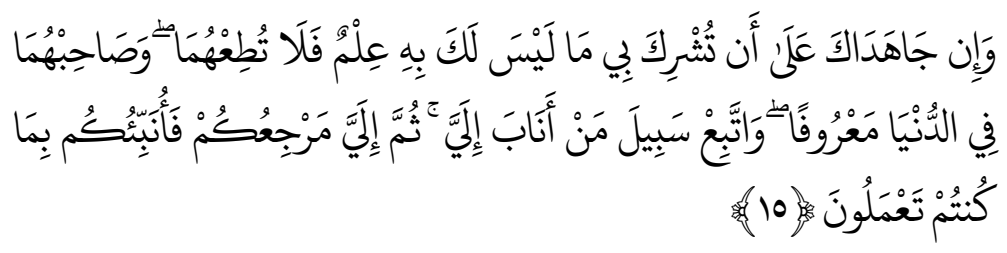

"Dan jika keduanya memaksamu untuk mempersekutukan dengan Aku sesuatu yang tidak ada pengetahuanmu tentang itu, maka janganlah kamu mengikuti keduanya, dan pergaulilah keduanya di dunia dengan baik, dan ikutilah jalan orang yang kembali kepada-Ku, kemudian hanya kepada-Kulah kembalimu, maka Kuberitakan kepadamu apa yang telah kamu kerjakan." (QS. Luqman [31]: 15).

Sesungguhnya orang tua adalah orang yang paling menyayangi anaknya, karena orang tua yang telah mendidik dan memelihara sejak kecil sampai tumbuh dewasa, menjadi seorang pelajar dan menuntut ilmu pengetahuan Islam. Oleh karena itu, terimalah nasihat dan petuahnya, karena orang tua lebih mengetahui sesuatu yang akan dihadapi oleh anak-anaknya. ${ }^{31}$

\footnotetext{
${ }^{30}$ Imam al-Ghazali, Ihya 'Ulum ad-Din, terj. Ismail Ya'kub, h. 197.

${ }^{31}$ Syaikh Muhammad Syakir, Washaya al-Aba' lil-Abna, h. 29.
} 


\section{Akhlak kepada Orang Lain}

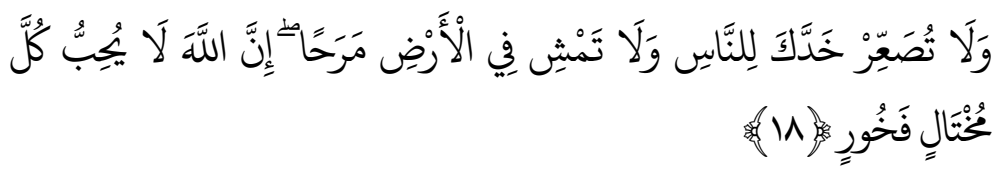

"Dan janganlah kamu memalingkan mukamu dari manusia (karena sombong) dan janganlah kamu berjalan di muka bumi dengan angkuh. Sesungguhnya Allah tidak menyukai orang-orang yang sombong lagi membanggakan diri." (QS. Luqman [31]: 18)

Ayat tersebut mengisyaratkan agar berbuat baik dan sopan santun dengan sesama manusia, yaitu dilarang untuk memalingkan mukanya yang didorong oleh penghinaan dan kesombongan. ${ }^{32}$ Kaitannya dengan kehidupan bermasyarakat. Anak-anak haruslah dididik untuk tidak bersikap acuh terhadap sesama, sombong atas mereka dan berjalan dimuka bumi ini dengan congkak. Karena perilaku-perilaku tersebut tidak disenangi oleh Allah dan dibenci manusia.

Syaikh Muhammad Syakir menjelaskan dalam kitab washaya al aba' 'lil abna' bahwa dengan orang lain dilarang menyakiti hatinya atau berlaku buruk terhadap orang lain. Ketika orang lain sedang mendapatkan kesulitan dalam belajar dan bertanya pada seorang guru, maka dengarkanlah baik-baik jawaban guru tersebut, mungkin dengan demikian akan mendapatkan faedah yang sebelumnya tidak diketahui. Hindarilah kata-kata yang menyinggung dan menghina orang lain dengan menunjukan wajah yang sinis karena kurang berkenan. Jika orang lain membutuhkan pertolongan, janganlah merasa berat untuk menolongnya, jauhkan sikap membanggakan diri bahwa dirinya mempunyai keutamaan daripada orang lain. ${ }^{33}$

\section{Akhlak kepada Diri Sendiri}

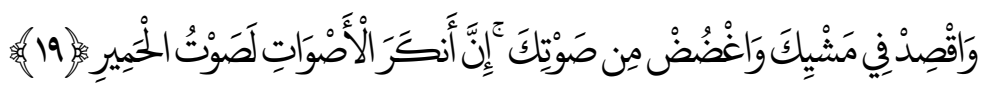

"Dan sederhanalah kamu dalam berjalan dan lunakkanlah suaramu. Sesungguhnya seburuk-buruk suara ialah suara keledai." (QS. Luqman [31]: 19)

${ }^{32}$ M. Quraish Shihab, Tafsir al-Mishbah, h. 139.

${ }^{33}$ Syaikh Muhammad Syakir, Washaya al-Aba' lil-Abna, h. 33. 
Bersamaan dengan larangan berjalan dengan congkak. Allah memerintahkan untuk sederhana dalam berjalan, dengan tidak menghempaskan tenaga dalam bergaya, tidak melengak-lengok, tidak memanjangkan leher karena angkuh, tetapi berjalan dengan sederhana, langkah sopan dan tegap. Memelainkan suara adalah budi yang luhur. Begitu pula percaya diri dan tenang karena berbicara jujur. Suara lantang (melengking) dalam berbicara termasuk perangai yang buruk. Tetapi, tampillah kepada setiap orang dengan wajah berseri penuh rendah hati dan berjalanlah dengan lemah lembut penuh wibawa, jangan membusungkan dada dan jangan merunduk bagaikan orang sakit. ${ }^{34}$

Demikian, Allah telah memberikan contoh kongkret mendidik akhlak anak-anak. Jika setiap orang tua dapat melaksanakannya dengan baik, maka besar harapan anak-anak tumbuh menjadi manusia-manusia Muslim yang berakhlak luhur.

\section{E. Metode Pendidikan Anak}

Pendidikan yang pertama bagi anak adalah pendidikan dalam keluarga. Anak-anak yang terlahir dari keluarga yang baik dan teratur tentunya akan mempunyai masa depan yang cerah, menjadi generasi yang baik. Sebaliknya, anak yang tidak terurus dan kurang kasih sayang dari orang tua kemungkinan besar anak tersebut menjadi generasi yang tidak sesuai dengan harapan bangsa dan agama. Di samping itu, anak merupakan amanat dari Allah yang harus dijalankan oleh kedua orang tuanya. Jadi orang tua harus benar-benar mendidik anak-anaknya secara benar agar ia mendapat kebahagiaan di dunia dan akhirat..$^{35}$ Adapun metode pendidikan akhlak adalah sebagai berikut:

\section{Metode Keteladanan (Uswatun Hasanah)}

Anak-anak memiliki kecenderungan atau sifat peniru yang sangat besar, maka metode uswatun hasanah "contoh teladan yang baik" dari orang-orang yang dekat dengan anak itu yang paling tepat. Dalam hal ini, orang yang paling dekat kepada anak adalah orang tuanya, karena itu contoh teladan dari orang tuanya sangat berpengaruh pada pembentukan mental dan akhlak anak-anak.

\footnotetext{
${ }^{34}$ M. Quraish Shihab, Tafsir al-Mishbah, h. 139.

${ }^{35} \mathrm{http} / / /$ perahujagad.blogspot.com/2012/06/metode-pendidikan-akhlak-studi-praktik. html\# chitika_close_button. diakses tanggal 30 November 2013.
} 
Keteladanan dalam pendidikan adalah metode yang paling meyakinkan keberhasilannya dalam mempersiapkan dan membentuk anak di dalam moral, spiritual dan sosial. Hal ini karena pendidik adalah contoh terbaik dalam pandangan anak yang akan ditirunya dalam tindak-tanduknya dan tata santunnya, disadari ataupun tidak, bahkan tercetak dalam jiwa dan perasaan suatu gambaran pendidik tersebut, baik dalam ucapan ataupun dalam perbuatan, baik material atau spiritual, diketahui atau tidak diketahui ${ }^{36}$ Masalah keteladanan menjadi faktor penting dalam hal buruknya anak. Jika pendidik jujur, dapat dipercaya, berakhlak mulia, berani dan manjauhkan diri dari perbuatan yang bertentangan dengan agama, maka anak akan tumbuh dalam kejujuran, terbentuk dengan akhlak mulia, keberanian dan dalam sikap yang menjauhkan diri dari perbuatan-perbuatan yang bertentangan dengan agama. Tetapi, jika pendidik bohong, khianat, durhaka, kikir, penakut, dan hina, maka si anak akan tumbuh dalam kebohongan, khianat, durhaka, kikir, penakut dan hina.

Allah mengutus Nabi Muhammad, sebagai teladan yang baik bagi umat Muslim sepanjang sejarah, dan bagi umat manusia disetiap saat dan tempat sebagai pelita yang menerangi sebagai purnama yang memberi petunjuk.

Dengan demikian, dapat diketahui oleh para ayah, ibu dan pendidik bahwa pendidikan dengan memberikan teladan yang baik adalah penopang dalam upaya meluruskan kebengkokan akhlak anak. Bahkan merupakan dasar dalam meningkatkan pada keutamaan, kemuliaan dan etika sosial yang terpuji. Tanpa memberikan teladan yang baik ini, pendidikan terhadap anak-anak tidak berhasil, dan nasihat tidak membekas. Oleh karena itu, pendidik bertakwalah kepada Allah dalam mendidik anak-anak. Mendidik anak-anak adalah tanggung jawab yang dibebankan atas pundak orang tua ataupun pendidik. Sehingga, dapat menyaksikan anak-anak sebagai "matahari perbaikan", "purnama petunjuk", yang masyarakat dapat menikmati sinarnya dan bercermin kepada akhlak meraka yang mulia.

\section{Metode Pembiasaan}

Sejak kecil anak harus dibiasakan untuk melakukan kegiatan-kegiatan yang baik, dilatih untuk bertingkah laku yang baik, diajari sopan santun dan sebagai-

${ }^{36}$ Abdullah Nashih Ulwan, Pedoman Pendidikan Anak dalam Islam, Juz II, terj., Drs. Saifullah Kamalie, Lc, Drs. Hery Noer Ali, Semarang, Asy Syifa', 1981, h. 2. 
nya. Mendidik, melatih, dan membimbing anak secara perlahan adalah hal yang wajib diterapkan pada anak agar dia dapat meraih sifat dan ketrampilan dengan baik, agar keyakinan dan akhlaknya tertanam dengan kokoh. Akhlak dan prinsip-prinsip keyakinan, termasuk di dalamnya ketrampilan anggota tubuh, membutuhkan adanya proses bertahap untuk dapat diraih dan harus dilakukan secara kebiasaan atau berulang-ulang sehingga tercapai dan dikuasai dengan baik, serta dapat dilaksanakan dengan mudah dan ringan, tanpa bersusah payah dan menemukan kesulitan. ${ }^{37}$ Anak merupakan anugerah sekaligus amanat yang diberikan Allah kepada manusia yang menjadi orang tuanya. Hatinya masih bersih dan suci. Baik dan buruknya seorang anak tergantung dari pendidikan yang diberikan kepadanya.

al-Ghazali dalam bukunya yang berjudul Ihya Ulumudin telah menyebutkan: "perlu diketahui bahwa jalan untuk melatih anak-anak termasuk urusan yang paling penting dan harus mendapat prioritas yang lebih penting dari yang lainya. Anak merupakan amanat ditangan kedua orang tuanya dan kalbunya yang masih bersih merupakan permata yang sangat berharga. Jika dibiasakan untuk melakukan kebaikan, niscaya ia akan tumbuh menjadi baik dan menjadi orang yang bahagia dunia dan akhirat. Sebaliknya jika dibiasakan dengan keburukan serta diterlantarkan seperti hewan ternak, niscaya dia akan menjadi orang yang celaka dan binasa". ${ }^{38}$ Oleh karena itu, jika mengambil metode Islam dalam mendidik kebiasaan, membentuk akidah dan budi pekerti, maka pada umumnya anak-anak akan tumbuh dalam akidah Islam yang kokoh, akhlak luhur, sesuai dengan ajaran al-Qur'an. Bahkan memberikan teladan kepada orang lain, dengan berlaku yang mulia dan sifatnya yang terpuji.

Maka, hendaklah para pendidik menyingsingkan lengan baju untuk memberikan hak pendidikan anak-anak dengan pengajaran, pembiasaan, dan pendidikan akhlak. Jika mereka telah melaksanakan upaya tersebut, berarti mereka telah menunaikan kewajiban dan tanggung jawabnya. Mendorong roda kemajuan pendidikan ke depan, mengokohkan pilar keamanan dan ketentraman dalam masyarakat. Ketika itu, kaum Mu'minin bersenang hati dengan hadirnya generasi Mu'min, masyarakat Muslim dan umat yang shalih.

\footnotetext{
${ }^{37}$ Muhammad Husain, Agar Anak Mandiri, terj., Nashirul Haq, (Bandung, Irsyad Baitus Salam, 2007), h. 11.

${ }^{38}$ Jamal 'Abdur Rahman, Tahapan Mendidik Anak Teladan Rasulullah SAW, (Bandung: Irsyad Baitus Salim, 2005), h. 29.
} 


\section{Metode Nasihat (Mau'izhah al-Hasanah )}

Nasihat dapat membukakan mata anak-anak pada hakikat sesuatu, mendorongnya menuju situasi luhur, menghiasi dengan akhlak yang mulia dan membekalinya dengan prinsip-prinsip Islam. Metode al-Qur'an dalam menyerukan dakwaan adalah bermacam-macam. Semua itu dimaksudkan sebagai upaya mengingat Allah menyampaikan nasihat dan bimbingan, yang semuanya berlangsung atas ucapan para Nabi as. Kemudian, dituturkan kembali oleh para da'i, dari kelompok dan pengikutnya. Nasihat yang tulus membekas dan berpengaruh, jika memasuki jiwa yang bening, hati terbuka, akal yang bijak, maka nasihat tersebut akan mendapat tanggapan secepatnya dan meninggalkan bekas yang dalam. ${ }^{39}$ al-Qur'an telah menegaskan pengertian ini dalam banyak ayatnya dan berulang kali menyebutkan manfaat dari peringatan. Allah berfirman:

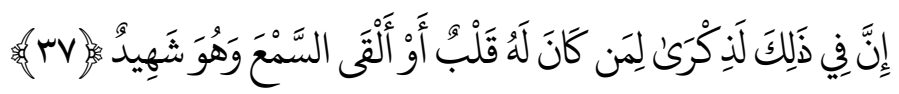

"Sesungguhnya pada yang demikian itu benar-benar terdapat peringatan bagi orang-orang yang mempunyai akal atau yang menggunakan pendengarannya, sedang Dia menyaksikannya." (QS. Qaaf [50]: 37)

\section{Metode Perhatian}

Metode pendidikan dengan perhatian adalah mencurahkan, memperhatikan dan senantiasa mengikuti perkembangan anak dalam pembinaan akidah dan akhlak, persiapan spiritual dan sosial selain itu juga bertanya tentang situasi pendidikan jasmani dan daya hasil ilmiahnya. Metode perhatian ini merupakan metode pendidikan yang terkuat dalam pembentukan manusia secara utuh dan dapat mendorongnya untuk menunaikan tanggung jawab dan kewajibannya secara sempurna. Melalui upaya tersebut akan tercipta Muslim yang hakiki. Allah berfirman:

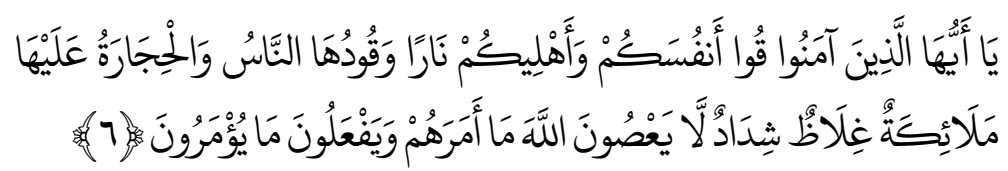

${ }^{39}$ Abdullah Nashih Ulwan, Pedoman Pendidikan Anak dalam Islam, h. 68 
"Hai orang-orang yang beriman, peliharalah dirimu dan keluargamu dari api neraka yang bahan bakarnya adalah manusia dan batu; penjaganya malaikat-malaikat yang kasar, keras, dan tidak mendurhakai Allah terhadap apa yang diperintahkan-Nya kepada mereka dan selalu mengerjakan apa yang diperintahkan." (QS. al-Tahrim [66]: 6)

\section{F. Strategi Pendidikan Akhlak pada Anak}

Secara etimologi, kata "strategi" dapat diartikan sebagai seni (art), yakni siasat atau rencana, sedangkan menurut kamus besar bahasa Indonesia mendefinisikan bahwa strategi adalah rencana yang cermat mengenai kegiatan untuk mencapai sasaran secara khusus. Menurut Joni strategi adalah suatu prosedur yang digunakan untuk memberikan suasana yang konduktif kepada siswa dalam rangka mencapai tujuan pembelajaran. ${ }^{40}$ Strategi pendidikan mengandung pengertian rangkaian perilaku pendidikan yang tersusun secara terencana dan sistematis untuk menginformasikan, mentransformasikan dan menginternalisasikan nilai-nilai Islam, dengan adanya strategi ini menjadikan anak lebih terarah sehingga dapat membentuk kepribadian Muslim seutuhnya.

Strategi pendidikan yang dapat dilakukan dalam upaya pendidikan atau pembinaan akhlak anak terdapat beberapa strategi yang digunakan diantaranya adalah:

\section{Pendidikan secara Langsung}

Pendidikan secara langsung yaitu dengan mengadakan hubungan langsung secara pribadi maupun secara kekeluargaan antara orang tua dengan anak, ketika dalam lingkungan keluarga atau guru dengan murid, ketika dalam lingkungan sekolah. caranya dengan mempergunakan petunjuk, nasihat, tuntunan dan lain sebagainya. Menurut Marimba, pendidikan secara langsung terdapat tiga macam $^{41}$ yaitu:

\section{a. Teladan}

Tingkah laku orang tua atau seorang guru secara langsung ditiru oleh anaknya. Ketika orang tua mengajari perbuatan baik anak mengikuti perbuatan

\footnotetext{
${ }^{40}$ Hamdani, Strategi Belajar Mengajar, (Bandung: Pustaka Setia, 2011), h. 18.

${ }^{41}$ Ahmad D. Marimba, Pengantar Filsafat Pendidikan Islam, (Bandung: al-Ma'arif, 1980), h. 85.
} 
baik tersebut, tetapi jika anak diajari perbuatan jelek seorang anak juga menirunya sesuai apa yang diajarkan oleh orang tuanya. Dengan teladan ini akan muncul tentang penyamaan diri dengan orang yang ditirunya. Sehingga segala bentuk ucapan maupun tindakan orang tua maupun guru ketika dalam lingkungan sekolah maka akan ditiru oleh anak-anaknya. Secara lambat laun seorang anak itu akan mengetahui dengan sendirinya bahwa perbuatan yang ia lakukan adalah merupakan kewajiban yang harus dilaksanakan tidak semata-mata karena mengikuti perilaku gurunya ataupun orang tuanya.

\section{b. Anjuran}

Anjuran yaitu saran atau ajakan untuk berbuat atau melakukan sesuatu yang baik dan berguna, dengan adanya anjuran menanamkan kedislipinan, melaksanakan kewajiban perintah agama pada anak, sehingga akhirnya menjalankan segala sesuatu dengan disiplin yang nantinya akan membentuk suatu kepribadian yang mulia. Seperti dalam sabda Rasulullah bahwa seorang anak ketika masih umur 7 tahun atau mungkin di bawahnya harus di ajak untuk melaksanakan shalat lima waktu. Anak-anak hendaklah diajak untuk mengerjakan shalat. Sehingga terbentuk manusia yang senantiasa kontak dengan penciptanya. Imam al-Ghazali menjelaskan bahwa seorang anak yang telah mencapai usia tamyiz, maka hendaklah tidak dibiarkan meninggalkan thaharah dan shalat. Juga mulai diperintahkan berpuasa beberapa hari di bulan Ramadhan. ${ }^{42}$

Nabi Muhammad bersabda:

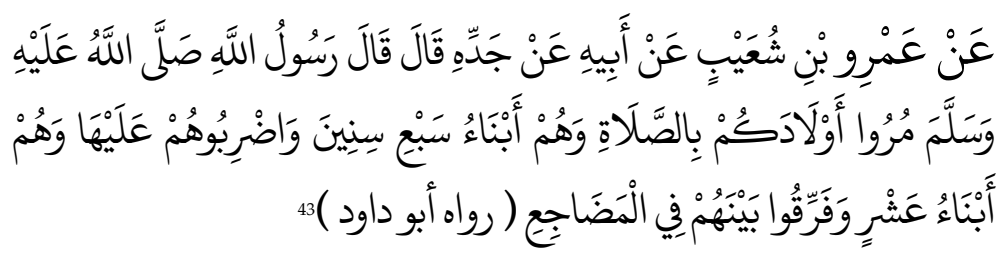

Dari Umar bin Syu'aib dari bapaknya dari kakeknya berkata: Rasulullah bersabda: "Perintahkanlah kepada anak-anak kalian untuk mengerjakan shalat bila mulai berusia 7 tahun dan pukullah mereka

\footnotetext{
42Imam al-Ghazali, Ihya 'Ulum ad-Din, terj. Ismail Ya'kub, h. 197.

${ }^{43} \mathrm{Abu}$ Daud Sulaiman bin al-Asy'at bin Ishaq bin Basyir bin Syadad bin Umar al-Azdi as-Sajistani Sunan Abi Daud, Juz 2, Maktabah Syamilah, h. 88.
} 
karena meninggalkannya karena telah berusia 10 tahun, dan pisahkanlah mereka dari tempat tidurnya masing-masing." (HR. Abu Dawud)

\section{c. Latihan}

Tujuan dari latihan adalah untuk menguasai gerakan-gerakan dan menghafalkan ucapan-ucapan. Orang tua ataupun guru harus selalu mengajari atau melatih anak untuk bertutur kata yang sopan, ramah, lembut dan santun, karena seorang anak mengikuti ucapan yang dilatih oleh orang tua maupun oleh gurunya. Tingkah laku seorang anak tergantung kepada siapa yang mengajarinya kalau anak tersebut dilatih uacapan ataupun perbuatan baik maka anak juga menjadi baik dan sebaliknya. Dalam hal melakukan ibadah, kesempurnaan gerakan dan ucapan ini sangat penting, misalnya seperti melakukan ibadah shalat. Seorang anak harus dilatih gerakan-gerakan shalat dan bacaan-bacaannya, karena jika anak tidak dilatih dengan gerakan ataupun bacaan maka anak tersebut tidak bisa melaksanakan shalat dengan baik dan sempurna. Selain itu juga dapat menanamkan sifat-sifat yang utama, misalnya kebersihan, keteraturan. Jadi anak tidak selalu bergantung pada orang lain (bisa melakukan diri sendiri) atau dilatih untuk mandiri dalam bahasa jawa seriang disebut dengan priyatin, tidak selalu bergantung pada orang tua. Dengan adanya latihan ini diharapkan bisa tertanamkan dalam hati atau jiwa mereka.

\section{Pendidikan Secara tidak Langsung}

Pendidikan secara tidak langung yaitu strategi pendidikan yang bersifat larangan atau pencegahan, penekanan. ${ }^{44}$ Strategi ini ada 3 macam, diantaranya adalah:

\section{a. Larangan}

Larangan ini merupakan suatu keharusan untuk tidak melakukan perbuatan yang bisa merugikan diri sendiri ataupun orang lain. Usaha ini merupakan tindakan tegas untuk menghentikan perbuatan-perbuatan yang sangat jelas kesalahannya. Larangan ini merupakan suatu perbuatan yang tidak pantas untuk dilakukan seperti mencuri, berkelahi dengan temannya, dan lain sebagainya. Perbuatan seperti ini harus dilarang sejak anak masih usia dini, agar ketika sudah dewasa nanti melakukan perbuatan yang dilarang oleh agama merupakan suatu

\footnotetext{
${ }^{44}$ Ahmad D. Marimba, Pengantar Filsafat Pendidikan Islam, h. 86.
} 
pantangan bagi dirinya. Strategi ini bertujuan untuk membentuk kedislipinan atau perbuata baik bagi anak.

\section{b. Hukuman}

Strategi hukuman ini merupakan suatu tindakan yang diberikan kepada anak yang secara sadar dan sengaja melakukan suatu kesalahan, sehingga dengan adanya hukuman ini anak muncul rasa penyelasan dan tidak melakukan kesalahan untuk yang kedua kalinya. Hukuman ini menghasilkan suatu kedisiplinan pada anak. Pada taraf yang lebih tinggi menginsyafkan anak untuk tidak melakukan suatu perbuatan yang dilarang oleh agama. Berbuat atau tidak berbuat bukan karena takut hukuman, melainkan karena keinsyafan sendiri dan merupakan suatu ketaatan pada Allah dan selalu mengharapkan ridha-Nya.

\section{c. Hadiah}

Pemberian hadiah kepada anak tidak selalu berupa materi atau barang, tetapi pemberian hadiah ini juga bisa berupa anggukan dengan wajah yang berseri-seri, acungan jempol dan lain sebagainya, itu semua sudah termasuk hadiah yang mempunyai pengaruh sangat besar kepada peserta didik. Karena, dengan adanya hadiah tersebut bisa menggembirakan anak, menambah kepercayaan pada diri sendiri dan yang lebih penting lagi bisa menjadi lebih semangat lagi dalam belajarnya.

\section{d. Pengawasan}

Strategi ini digunakan untuk menjaga agar tidak terjadi hal-hal yang tidak diinginkan. Karena manusia tidaklah sempurna, jadi kemungkinan besar selalu melakukan kesalahan-kesalahan, penyimpangan-penyimpangan ini selalu ada. Maka dari itu, sebelum kesalahan dan penyimpangan itu dilakukan lebih jauh, sebaiknya selalu ada usaha untuk diadakan pengawasan. Apalagi zaman sekarang anak-anak sudah pandai memainkan gadget, dalam hal ini orang tua harus bisa benar-benar mengawasi, karena kalau tidak diawasi nanti anak-anak bisa membuka situs-situs yang terlarang yang semua itu merusak moral dan akhlak anak.

\section{G. Kesimpulan}

Penanaman pendidikan akhlak pada masa anak-anak sangatlah penting, agar anak memiliki bekal untuk hidup selanjutnya. Pendidikan akhlak harus 
dilakukan sejak dini, sebelum watak dan kepribadiannya terpengaruh lingkungan yang tidak paralel dengan tuntunan agama. Oleh karena itu, dalam mendidik anak perlu adanya perhatian khusus bagi orang tua maupun guru di sekolah. Karena baik dan buruknya perilaku anak, bergantung pada pendidikan yang diberikan kepada anak tersebut, jika anak tersebut dididik dengan akhlak yang baik pasti anak tersebut menjadi anak yang baik dan sebaliknya. Maka dalam hal ini perlu diadakan sebuah metode ataupun strategi khusus untuk mendidik anak, agar anak bisa menjadi manusia yang mempunyai akhlak yang mulia dan menjadi anak yang sholeh dan sholehah. Diantara metode pendidikan akhlak anak adalah metode pembiasaan, metode keteladanan, metode nasihat dan metode perhatian. Kemudian untuk strategi pendidikan akhlaknya ini dibagi menjadi dua, pendidikan langsung dan pendidikan tidak langsung. Pendidikan langsung dianatarnya adalah keteladanan, anjuran, latihan. Pendidikan tidak langsung diantaranya adalah larangan, hukuman, hadiah dan pengawasan.]

\section{Daftar Pustaka}

Abdullah Ahmad bin Muhammad bin Hanbal bin Hilal bin Asad asy-Syaibani, Musnad Ahmad, Juz 13 dan 14, Maktabah Syamilah.

Abdullah, Yatimin, Studi Akhlak dalam Perspektif al-Qur'an, Jakarta: Sinar Grafika Offset, 2007.

Dasuki, A. Hafizh et. al, Ensiklopedi Islam, Juz I, cet-3, Jakarta: PT. Ichtiar Baru van Hoeve, 1994.

Daud Sulaiman bin al-Asy'at bin Ishaq bin Basyir bin Syadad bin Umar al-Azdi as-Sajistani, Sunan Abu Dawud, Juz 12, Maktabah Syamilah

Departemen Pendidikan Nasional, Kamus Besar Bahasa Indonesia, Jakarta: Gramedia ustaka Utama, 2013.

Ghazali, Imam, Ihya Ulumudin, Jilid III, Jeddah Indonesia: al Haramain, t.th.

-_-., Ihya 'Ulum ad-Din, terj. Ismail Ya'kub, Jakarta: Faisan, 1986, Jilid IV.

al-Hafidz Abi 'Abdillah Muhammad bin Yazid al-Qozwini, Sunan Ibnu Majjah, Juz II, Beirut: Dar al-Fikr, t.th.

Hamdani, Strategi Belajar Mengajar, Bandung, Pustaka Setia, 2011. 
Husain, Muhammad, Agar Anak Mandiri, terj., Nashirul Haq, Bandung: Irsyad Baitus Salam, 2007.

Mahani, Muhamad Kamil Hasan, Ensiklopedia al-Qur'an, terj. Ahmad Fawaid Syadzili, Jakarta: PT Kharisma Ilmu, 2005

Mahmud, Pemikiran Pendidikan Islam, Bandung: CV. Setia Pustaka, 2011.

Morrison, George S, Dasar-dasar Pendidikan Anak Usia Dini (PAUD), Jakarta: Indeks, 2012.

Muhammad Isma'il bin Ibrahim bin al-Mughiroh al-Bukhari, Shahih Bukhari, Juz 5, Maktabah Syamilah.

Muslim bin al-Hajjaj Abu al-Hasan al-Qusyairi Shahih Muslim, Juz 12, Maktabah Syamilah

Nata, Abuddin, Akhlak Tasawuf, Jakarta: Rajawali Pers, 2010.

al-Qur'an, al-Qur'an dan Terjemahnya Departemen Agama RI, Jakarta: Darus Sunnah, 2010.

Rahman, Jamal 'Abdur, Tahapan Mendidik Anak Teladan Rasulullah SAW, Bandung: Irsyad Baitus Salim, 2005.

Saebani, Beni Ahmad dan Abdul Hamid, Ilmu Akhlak, Bandung: Pustaka Setia, 2010.

Shihab, M. Quraish, Tafsir Al Mishbah, Juz 11, Jakarta: Lentera Hati, 2005.

Syakir, Muhammad, Washoya al-Aba' lil-Abna', Semarang: Alawiyah, t.th. , Muhammad, Wasiat Ayah kepada Anak-anak, terj., Ramzi Abdul Aziz, Surabaya: Putra Harsa, t.th.

Ulwan, Abdullah Nashih, Pedoman Pendidikan Anak dalam Islam, Juz II, terj., Saifullah Kamalie, Hery Noer Ali, Semarang: Asy Syifa', 1981.

Undang-undang Sistem Pendidikan Nasional, Bandung: Fokus Media, 2009.

Zainudin, dkk, Seluk Beluk Pendidikan dari al-Ghazali, Bandung: Bumi Aksara, 1991.

http://aziz91mei.blogspot.com/2012/10/fenomena-dekadensi-moral-di-era. html

http://perahujagad.blogspot.com/2012/06/metode-pendidikan-akhlak-studipraktik 
